OPEN ACCESS

Edited by:

Sanjeev Kumar

Physical Research Laboratory, India

Reviewed by

Manab Kumar Dutta,

Physical Research Laboratory, India

Perran Cook

Monash University, Australia

*Correspondence:

Neus Garcias-Bonet

neus.garciasbonet@kaust.edu.sa

Specialty section:

This article was submitted to Marine Biogeochemistry,

a section of the journal

Frontiers in Marine Science

Received: 31 July 2017

Accepted: 12 October 2017

Published: 07 November 2017

Citation:

Garcias-Bonet N and Duarte CM

(2017) Methane Production by

Seagrass Ecosystems in the Red Sea.

Front. Mar. Sci. 4:340

doi: 10.3389/fmars.2017.00340

\section{Methane Production by Seagrass Ecosystems in the Red Sea}

\author{
Neus Garcias-Bonet* and Carlos M. Duarte \\ Red Sea Research Center, King Abdullah University of Science and Technology, Thuwal, Saudi Arabia
}

Atmospheric methane $\left(\mathrm{CH}_{4}\right)$ is the second strongest greenhouse gas and it is emitted to the atmosphere naturally by different sources. It is crucial to define the dimension of these natural emissions in order to forecast changes in atmospheric $\mathrm{CH}_{4}$ mixing ratio in future scenarios. However, $\mathrm{CH}_{4}$ emissions by seagrass ecosystems in shallow marine coastal systems have been neglected although their global extension. Here we quantify the $\mathrm{CH}_{4}$ production rates of seagrass ecosystems in the Red Sea. We measured changes in $\mathrm{CH}_{4}$ concentration and its isotopic signature by cavity ring-down spectroscopy on chambers containing sediment and plants. We detected $\mathrm{CH}_{4}$ production in all the seagrass stations with an average rate of $85.09 \pm 27.80 \mu \mathrm{mol} \mathrm{CH} \mathrm{Cm}^{-2} \mathrm{~d}^{-1}$. Our results show that there is no seasonal or daily pattern in the $\mathrm{CH}_{4}$ production rates by seagrass ecosystems in the Red Sea. Taking in account the range of global estimates for seagrass coverage and the average seagrass $\mathrm{CH}_{4}$ production, the global $\mathrm{CH}_{4}$ production and emission by seagrass ecosystems could range from 0.09 to $2.7 \mathrm{Tg} \mathrm{yr}^{-1}$. Because $\mathrm{CH}_{4}$ emission by seagrass ecosystems had not been included in previous global $\mathrm{CH}_{4}$ budgets, our estimate would increase the contribution of marine global emissions, hitherto estimated at $9.1 \mathrm{Tg} \mathrm{yr}^{-1}$, by about $30 \%$. Thus, the potential contribution of seagrass ecosystems to marine $\mathrm{CH}_{4}$ emissions provides sufficient evidence of the relevance of these fluxes as to include seagrass ecosystems in future assessments of the global $\mathrm{CH}_{4}$ budgets.

Keywords: methane, greenhouse gas, seagrass ecosystems, cavity ring-down spectroscopy, Red Sea

\section{INTRODUCTION}

Atmospheric methane $\left(\mathrm{CH}_{4}\right)$ is a strong greenhouse gas (Lashof and Ahuja, 1990), with a 34-fold higher global warming potential relative to the $\mathrm{CO}_{2}$ for a time horizon of 100 years, taking in account the climate-carbon feedback (IPCC, 2013). Atmospheric $\mathrm{CH}_{4}$ mixing ratio has more than doubled from $722 \mathrm{ppb}$ in pre-industrial times to 1,803 ppb in 2011 (IPCC, 2013) with high inter-annual variability. The highest rates of $\mathrm{CH}_{4}$ growth have been reported for the 1980's (12 ppb $\left.\mathrm{yr}^{-1}\right)$ followed by a decrease in the 1990's $\left(6 \mathrm{ppb} \mathrm{yr}^{-1}\right)$ and the lowest growth rate $\left(2 \mathrm{ppb} \mathrm{yr}^{-1}\right)$ or even stabilization of $\mathrm{CH}_{4}$ atmospheric levels in the 2000's (Dlugokencky et al., 2003; Kirschke et al., 2013). Since 2007, atmospheric $\mathrm{CH}_{4}$ mixing ratio is increasing at high rates again $\left(10 \mathrm{ppb} \mathrm{yr}^{-1}\right.$; Rigby et al., 2008). The causes of this inter-annual variability in the growth rate of $\mathrm{CH}_{4}$ remain unclear, with difficulties in attributing this trend to specific contributions of different sources (biogenic, thermogenic, and pyrogenic emissions) and sinks (mostly, photo-oxidation by hydroxyl free radicals in the troposphere) (Bousquet et al., 2006; Kirschke et al., 2013; McNorton et al., 2016; Turner et al., 2017). The biogenic sources of methane include natural and anthropogenic emissions from wetlands, agriculture, fresh water reservoirs and oceans, ruminants, termites and organic waste. 
Bottom-up estimates identify biogenic emissions from natural freshwater wetlands as the main sources of $\mathrm{CH}_{4}$ since 1980 (Kirschke et al., 2013). In the last decade, the average global $\mathrm{CH}_{4}$ emissions by wetlands was estimated at $190 \mathrm{Tg} \mathrm{CH}_{4} \mathrm{yr}^{-1}$, ranging from 177 to $284 \mathrm{Tg} \mathrm{CH}_{4} \mathrm{yr}^{-1}$ due to uncertainties mainly in coverage estimates (Kirschke et al., 2013; Melton et al., 2013). Oceanic and marine systems are also net sources of $\mathrm{CH}_{4}$ although with lower global emissions than other sources. Yet, $\mathrm{CH}_{4}$ emissions reported for the coastal ocean (5.5 and $1.9 \mathrm{Tg} \mathrm{CH}_{4} \mathrm{yr}^{-1}$ for the continental shelf and estuaries, respectively; Rhee et al., 2009; EPA, 2010) exceed those reported from the open ocean (1.8 $\mathrm{Tg} \mathrm{CH}_{4} \mathrm{yr}^{-1}$; EPA, 2010), despite the coastal ocean represents $<15 \%$ of the global ocean area. The sources of $\mathrm{CH}_{4}$ in the oceans are both biogenic, mediated by microbial processes, and thermogenic, through marine seeps. In open waters, biogenic $\mathrm{CH}_{4}$ can be produced anaerobically by methanogens associated to particulate organic matter (Karl and Tilbrook, 1994; EPA, 2010) and aerobically as by-products during phosphonate uptake by heterotrophic bacteria under phosphate-limiting conditions (Karl et al., 2008). In coastal waters, biogenic $\mathrm{CH}_{4}$ is mainly produced in sediments by anaerobic methanogenesis decomposing organic matter. Anaerobic methanogenesis requires anoxic conditions and redox potentials lower than $-100 \mathrm{mV}$ (Conrad, 2007), typically found in marine sediments (Gray, 1981). The contribution of seep and groundwater sources to $\mathrm{CH}_{4}$ emissions in coastal waters remains unclear. Few data are available for oceanic $\mathrm{CH}_{4}$ fluxes compared to other natural and anthropogenic sources. Oceanic $\mathrm{CH}_{4}$ emissions were omitted in earlier assessments and have only been included in the last, the fifth, IPCC Assessment Report (IPCC, 2013), although its contribution accounts for 1-4\% of the global $\mathrm{CH}_{4}$ emissions. The paucity of data is especially important for tropical latitudes and for estuaries and shallow coastal areas, where the role of sediments colonized by seagrasses has been largely neglected. Indeed, $\mathrm{CH}_{4}$ production rates, ranging from 5.8 to $307.2 \mu \mathrm{mol} \mathrm{CH}_{4} \mathrm{~m}^{-2} \mathrm{~d}^{-1}$ on average, have been only reported for 4 different seagrass species in 5 locations (Table 1).

Seagrass ecosystems cover shallow coastal areas from all continents, except Antarctica, with an estimated global coverage ranging from $0.15 \times 10^{6}$ to $4.32 \times 10^{6} \mathrm{Km}^{2}$ (Duarte, 2017). Thus, due to their global coverage, high productivity and high organic matter content in their sediments supporting high microbial activity compared to adjacent bare sediments, seagrass ecosystems could represent a potential important source to be included in global $\mathrm{CH}_{4}$ budgets. Here, we report $\mathrm{CH}_{4}$ production rates by seagrass ecosystems along the eastern Red Sea coast, encompassing 7 different species distributed across 9 locations spanning 10 degrees latitude. Moreover, in one of the seagrass meadow we measured $\mathrm{CH}_{4}$ production rates periodically during 1 year in order to examine the existence of seasonal patterns.

\section{MATERIALS AND METHODS}

We sampled 9 seagrass stations (S1-S9) along the Saudi coast of the Red Sea, onboard the R/V Thuwal on March 2017 as part of a scientific cruise covering more than $1,300 \mathrm{~km}$ of the Saudi Red
Sea coast (Figure 1). The Red Sea is the northernmost tropical sea, reaching the $28^{\circ} \mathrm{N}$ parallel, with an extension of about $450,000 \mathrm{~km}^{2}$ and an average depth of $490 \mathrm{~m}$ (Bruckner et al., 2012). Approximately $25 \%$ of its extension is occupied by shallow shelves (less than $50 \mathrm{~m}$ deep) holding rich and diverse marine ecosystems (Rasul et al., 2015). We sampled 7 different seagrass species: 7 stations out of the total were monospecific meadows and the other 2 were mixed meadows. Moreover, in one of the stations, an Enhalus acoroides meadow adjacent to our laboratory (S5), we also sampled periodically during 1 year, starting on June 2016 until April 2017, in order to detect seasonal patterns in $\mathrm{CH}_{4}$ emissions.

At each station and sampling event, we collected 3 or 4 replicated cylindrical plastics cores (inner diameter $=9.5 \mathrm{~cm}$, height $=30 \mathrm{~cm}$ ) containing $\sim 10 \mathrm{~cm}$ of sediment (without disturbing its structure) and seagrass shots, in order to measure $\mathrm{CH}_{4}$ production rates. We used a rubber hammer to push the plastic cores down into the sediment. The lower edges of the plastic cores were sharpened in order to facilitate the penetration of the cores into the seagrass meadow sediments. Once the core was at the desired depth into the sediment $(\sim 10 \mathrm{~cm})$, we closed the upper end with a rubber cap and pulled the core up carefully, ensuring that the sediment structure was not disturbed and finally we closed immediately the lower end of the core with another rubber cap. For those stations sampled during the scientific cruise, the cores were transported immediately onboard and were secured on the upper deck in incubators equipped with a running seawater system, maintaining the temperature close to in situ temperature. For the periodical sampling events at station S5, the cores were transported immediately to the laboratory and placed in an incubator (Percival chambers) set at in situ temperature and simulating the natural photoperiod $(12 \mathrm{~h}$ light: $12 \mathrm{~h}$ dark). At the end of each incubation, we collected the aboveground seagrass tissues present in each core, in order to calculate the aboveground seagrass biomass. We dried the plant material at $60^{\circ} \mathrm{C}$ and recorded the dry weight. Additionally, we collected 3 cores to analyze the organic matter and nutrient $(\mathrm{C}$ and $\mathrm{N}$ ) content of the sediment from each station. The organic matter content was estimated by loss on ignition method, while the $\mathrm{C}$ and $\mathrm{N}$ concentration were analyzed on an CHN Elemental Analyzer (Flash 2000) after acidification of the sediment samples, in order to remove carbonates.

\section{$\mathrm{CH}_{4}$ Concentrations in Equilibrated Air}

The concentration of $\mathrm{CH}_{4}$ in equilibrated air along with its isotopic composition $\left(\delta^{13} \mathrm{C}-\mathrm{CH}_{4}\right)$ was measured by cavity ring-down spectroscopy (Picarro G2201-i). The precision and accuracy of the $\mathrm{CH}_{4}$ concentration analysis was \pm 0.01 and \pm 0.05 pmm, respectively. The precision and accuracy of the $\delta^{13} \mathrm{C}-\mathrm{CH}_{4}$ analysis was \pm 0.02 and $\pm 1.01 \%$, respectively. We used an air mixture $\left(\mathrm{CH}_{4}\right.$ concentration $=9.7 \mathrm{ppm}$ and $\mathrm{CO}_{2}$ concentration $=750$ ppm, Abdullah Hashim Industrial Gases \& Equipment Co. Ltd., Jeddah, Saudi Arabia) as a standard for the gas concentrations and Stable Isotope Calibration Standard UN1956 $\left(\delta^{13} \mathrm{C}-\mathrm{CH}_{4}=-45 \%\right.$, Air Liquide America Specialty Gases, Plumsteadville, PA, USA), as standard for the isotopic signature. We analyzed the concentration and isotopic composition of 
TABLE 1 | $\mathrm{CH}_{4}$ production rates by seagrasses reported in the literature and in this study.

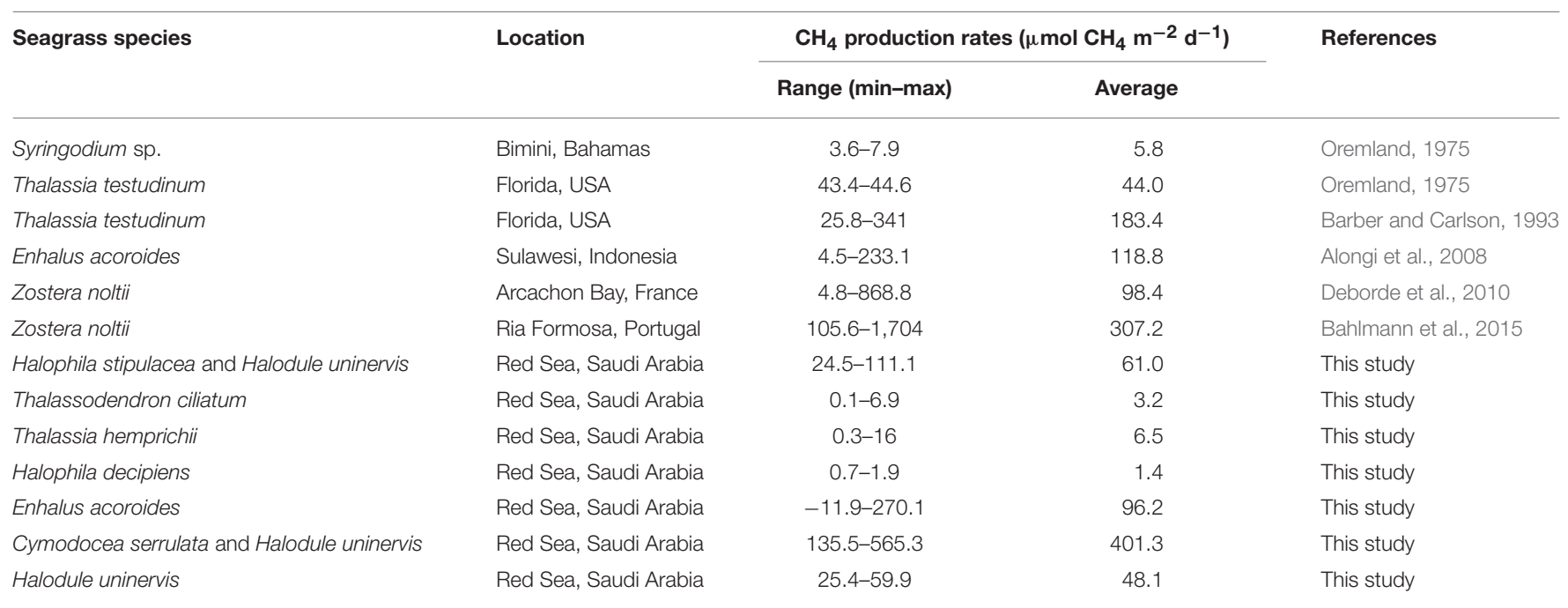

The $\mathrm{CH}_{4}$ production rates from this study are averaged rates per each seagrass species, pooling data from different stations or sampling events.

$\mathrm{CH}_{4}$ in equilibrated air in two different setups. First, for the stations sampled during the scientific cruise and analyzed on board we used the headspace technique (section Headspace Technique: Discrete Gas Sample Analysis) and, second, for the cores collected at station S5 along 1 year we used the closed recirculating circuits technique with the cores placed in the laboratory incubation system (section Closed Recirculating Circuits: In Continuum Gas Analysis).

Headspace Technique: Discrete Gas Sample Analysis Once on board the research vessel, the upper cap of the core was removed and seawater from the core was replaced by fresh seawater from the running surface seawater system without disturbing the sediment. Seawater temperature and salinity was recorded for further calculations. The cores were closed again with a stopper fitted with a gas-tight valve, leaving a headspace of about $250 \mathrm{ml}$. The specific volume of the sediment, seawater and headspace of each core was calculated. We left the cores to stabilize for $1 \mathrm{~h}$ until the first headspace sample was taken. The air sample $(15 \mathrm{ml})$ from the headspace of each replicate core was withdrawn with a syringe through the gas-tight valve and the $\mathrm{CH}_{4}$ concentration along with its isotopic composition $\left(\delta^{13} \mathrm{C}\right.$ $\mathrm{CH}_{4}$ ) were analyzed immediately on board using a cavity ringdown spectrometer (Picarro G2201-i), equipped with a module for discrete small volume gas samples (Picarro Small Sample Isotope Module, SSIM A0314). Several headspace samples were taken for each core at 3-7 time intervals along the incubation and analyzed in the cavity ring-down spectrometer. The incubations lasted about $24 \mathrm{~h}$ for all the stations, thereby encompassing day and night periods, except for station S3 for which the incubation was extended up to $35.43 \mathrm{~h}$.

\section{Closed Recirculating Circuits: In Continuum Gas Analysis}

Once the cores were settled in the incubator chamber in the laboratory, the seawater from the core was replaced by fresh

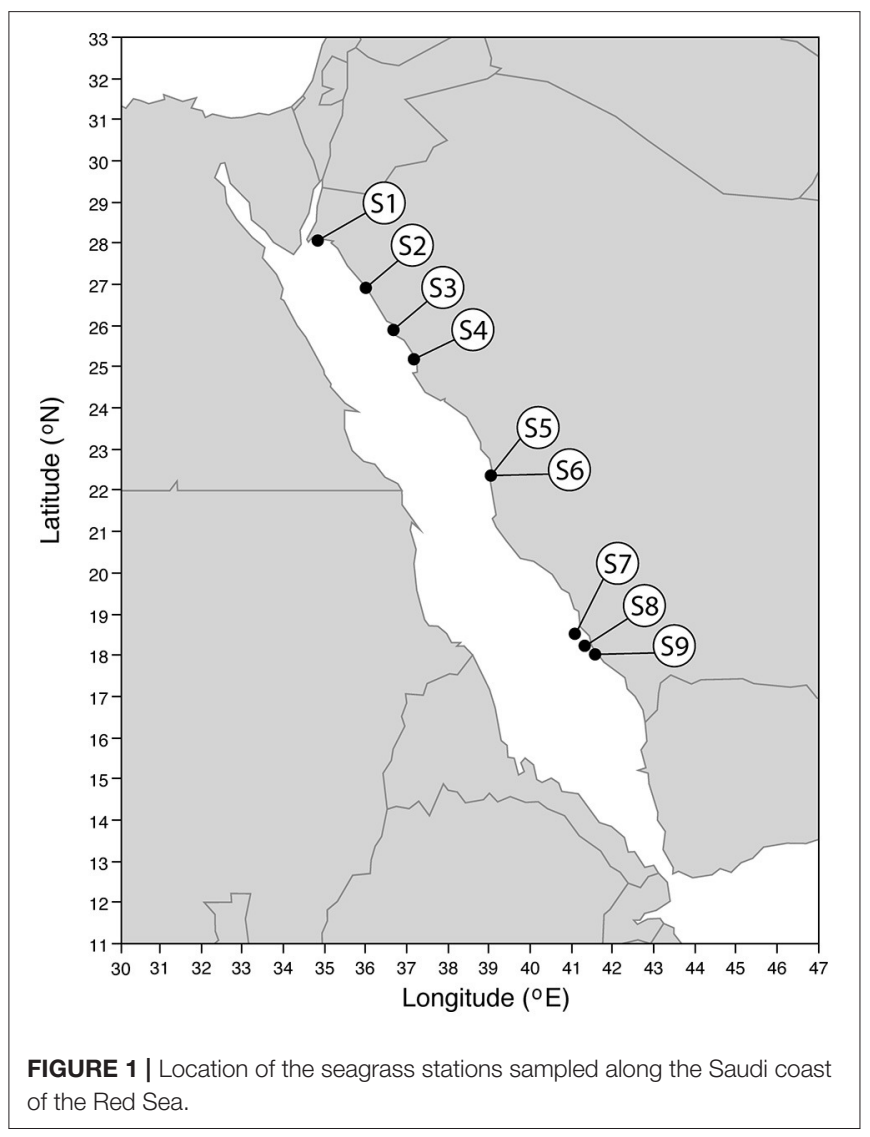

seawater collected from the same location without disturbing the sediments. The cores were closed again with a stopper with two holes fitted with silicone tubbing connected to an air-water exchange module to equilibrate the gas concentration in the closed water circuit with that in the closed air circuit. The closed seawater circuit was filled with seawater, 
carefully removing any gas bubble. The seawater was pumped through the air-water exchange module with a peristaltic pump, recirculating the seawater from the core. The closed air circuit was connected to the cavity ring-down spectrometer (Picarro G2201-i), thereby continuously recording the $\mathrm{CH}_{4}$ concentration in the air, equilibrated with the water circuit, along with its isotopic composition $\left({ }^{13} \mathrm{C}-\mathrm{CH}_{4}\right)$. These incubations lasted for at least $1 \mathrm{~h}$, allowing net $\mathrm{CH}_{4}$ production rates to be established, and were performed under light $(200 \mu \mathrm{mol}$ photons $\mathrm{m}^{-2} \mathrm{~s}^{-1}$ ) and dark conditions for each of the samplings.

\section{$\mathrm{CH}_{4}$ Concentration in Seawater}

The concentration of dissolved $\mathrm{CH}_{4}$ in seawater (in $\mathrm{nmol} \mathrm{CH}_{4}$ $\mathrm{L}^{-1}$ ) was calculated from the concentration of $\mathrm{CH}_{4}$ (in ppm) measured in air samples after equilibration from both approaches (discrete headspace samples and closed circuit in continuum) as described previously for other gases (Wilson et al., 2012). Briefly, we calculate the dissolved $\mathrm{CH}_{4}$ remaining in seawater after equilibration with the air phase $\left(\left[\mathrm{CH}_{4}\right]_{S W-e q}\right)$ by,

$$
\left[\mathrm{CH}_{4}\right]_{S W-e q}=10^{-6} \beta\left[\mathrm{CH}_{4}\right]_{\text {Air }} \mathcal{P}
$$

where $\beta$ is the Bunsen solubility coefficient of $\mathrm{CH}_{4}$, calculated according Wiesenburg and Guinasso (1979), as a function of seawater temperature and salinity; $\left[\mathrm{CH}_{4}\right]_{\text {Air }}$ is the $\mathrm{CH}_{4}$ concentration measured in the air from headspace samples or closed air circuit (in ppm) and $\mathcal{P}$ is the atmospheric pressure (in atm) of dry air that was corrected by the effect of multiple sampling applying Boyle's Law. Then, the initial $\mathrm{CH}_{4}$ concentration in seawater before the equilibrium ( $\left[\mathrm{CH}_{4}\right]_{S W \text {-before eq }}$ ) was calculated (in $\mathrm{ml} \mathrm{CH}_{4} / \mathrm{ml} \mathrm{H}_{2} \mathrm{O}$ ) by,

$$
\begin{aligned}
{\left[\mathrm{CH}_{4}\right]_{S W-\text { before eq }}=} & \left(\left[\mathrm{CH}_{4}\right]_{S W-e q} V_{S w}+10^{-6}\left(\left[\mathrm{CH}_{4}\right]_{\text {Air }}\right.\right. \\
& \left.\left.-\left[\mathrm{CH}_{4}\right]_{\text {Air background }}\right) V_{\text {Air }}\right) / V_{S W}
\end{aligned}
$$

where $V_{S w}$ is the volume of seawater in the core or in the seawater closed circuit, $\left[\mathrm{CH}_{4}\right]_{\text {Air background }}$ is the atmospheric $\mathrm{CH}_{4}$ background level and $V_{\text {Air }}$ is the volume of the headspace or the closed air circuit. Finally, the initial $\mathrm{CH}_{4}$ concentration was transformed to nmol $\mathrm{CH}_{4} \mathrm{~L}^{-1}$ by applying the ideal gas law.

\section{$\mathrm{CH}_{4}$ Production Rates by Seagrass Meadows}

$\mathrm{CH}_{4}$ production rates (in $\mathrm{nmol} \mathrm{CH}_{4} \mathrm{~L}^{-1} \mathrm{~h}^{-1}$ ) were calculated based on the change in the concentration of $\mathrm{CH}_{4}$ during the incubation time for each replicate core for each station and each sampling event. Then, we converted the rates to a daily and aerial (taking in account the core surface) base (in $\mu \mathrm{mol}$ $\left.\mathrm{CH}_{4} \mathrm{~m}^{-2} \mathrm{~d}^{-1}\right)$.

\section{Isotopic Composition $\left(\delta^{13} \mathrm{C}\right)$ of the Source $\mathrm{CH}_{4}$}

The isotopic composition $\left(\delta^{13} \mathrm{C}\right)$ of the source $\mathrm{CH}_{4}$, i.e., $\mathrm{CH}_{4}$ produced by seagrass ecosystems, in the Red Sea was analyzed by conducting keeling plots (Thom et al., 1993) for each of the seagrass stations sampled in this study. The $\delta^{13} \mathrm{C}$ of the source $\mathrm{CH}_{4}$ was inferred from the $\mathrm{Y}$ axis intercept of the linear regression between the inverse of the $\mathrm{CH}_{4}$ concentration measured in the equilibrated air (in $\mathrm{ppm}^{-1}$ ) and its $\delta^{13} \mathrm{C}-\mathrm{CH}_{4}$ during our incubations.

\section{RESULTS}

Methane production was detected at all seagrass meadows sampled, although the $\mathrm{CH}_{4}$ emission rate varied greatly among replicates within stations and among stations (Figure 2). Some incubations reached a $\mathrm{CH}_{4}$ concentration as high as $8,521.56 \mathrm{nM}$, (Figure 2, S6 replicate 1), whereas in others the $\mathrm{CH}_{4}$ concentration remained very low throughout the incubation time (Figure 2, S4 replicate 2). Some incubations showed a linear increase in $\mathrm{CH}_{4}$ concentration (Figure 2, S2 and S6), but in other incubations $\mathrm{CH}_{4}$ concentration experienced fluctuations (Figure 2, S1 and S3), indicative of methanogenesis and methanotrophy processes. Moreover, the isotopic $\delta^{13} \mathrm{C}$ signature of $\mathrm{CH}_{4}$ decreased when $\mathrm{CH}_{4}$ concentration increased, confirming its biogenic origin amidst the largely thermogenic background of Red Sea waters. Conversely, the isotopic $\delta^{13} \mathrm{C}$ signature of $\mathrm{CH}_{4}$ increased when $\mathrm{CH}_{4}$ was oxidized by methanotrophs. The biogenic origin of the $\mathrm{CH}_{4}$ produced in our seagrass incubations was confirmed by the $\delta^{13} \mathrm{C}$ of source $\mathrm{CH}_{4}$, inferred from keeling plots (Figure 3). The mean $\delta^{13} \mathrm{C}$ of the $\mathrm{CH}_{4}$ produced by seagrasses in the Red Sea was $-59.36 \%$, ranging from -73.81 to $-46.65 \%$ o (Table 2 ).

The $\mathrm{CH}_{4}$ production rates varied among stations, ranging from 0.09 to $565.27 \mu \mathrm{mol} \mathrm{CH} \mathrm{m}^{-2} \mathrm{~d}^{-1}$ (Table 2) with an overall mean of $85.09 \pm 27.8 \mu \mathrm{mol} \mathrm{CH}_{4} \mathrm{~m}^{-2} \mathrm{~d}^{-1}$ for the Red Sea seagrass meadows studied here. The lowest rates were detected in a Thalassodendron ciliatum meadow, followed by Thalassia hemprichii and Halophila decipiens meadows and the highest rates were detected in a Cymodocea serrulata and Halodule uninervis mixed meadow. The $\mathrm{CH}_{4}$ production rates increased with sediment organic matter content (Figure 4A, $R^{2}=0.54$, $p<0.0001$ ), and less strongly with increasing salinity (Figure $4 \mathbf{B}$, $R^{2}=0.39, p=0.0003$ ) and temperature (Figure $4 \mathrm{C}, R^{2}=$ $0.23, p=0.0092$ ). The highest $\mathrm{CH}_{4}$ production rates were observed in seagrass growing in enclosed marine coastal lagoons and the lowest rates were observed in pristine areas in shallow lagoons offshore from the mainland (Figure 4D, non-linear log fit $\left.R^{2}=0.54\right)$. The $\mathrm{CH}_{4}$ production rates were independent of sediment nutrient $(\mathrm{C}$ and $\mathrm{N})$ concentration $(p=0.77$ and $p=$ 0.25 , respectively) or aboveground seagrass biomass $(p=0.11)$.

There was no evident seasonal pattern in $\mathrm{CH}_{4}$ production rates at the Enhalus acoroides seagrass meadow (Station S5) sampled along the year, with an annually averaged daily $\mathrm{CH}_{4}$ production rate of $92.1 \pm 21.2 \mu \mathrm{mol} \mathrm{CH}_{4} \mathrm{~m}^{-2} \mathrm{~d}^{-1}$. The $\mathrm{CH}_{4}$ production rates measured under light and dark conditions (Figure 5A) and the daily rates (Figure 5B) did not differ among the five sampling events (ANOVA test, $p=0.43, p=0.79$, and $p=0.74$, respectively). Similarly, there was no clear daily pattern in the $\mathrm{CH}_{4}$ production rates with no tendency for rates under the light to be consistently higher or lower than those measured under dark conditions (Figure 6). The annual mean of the $\mathrm{CH}_{4}$ 

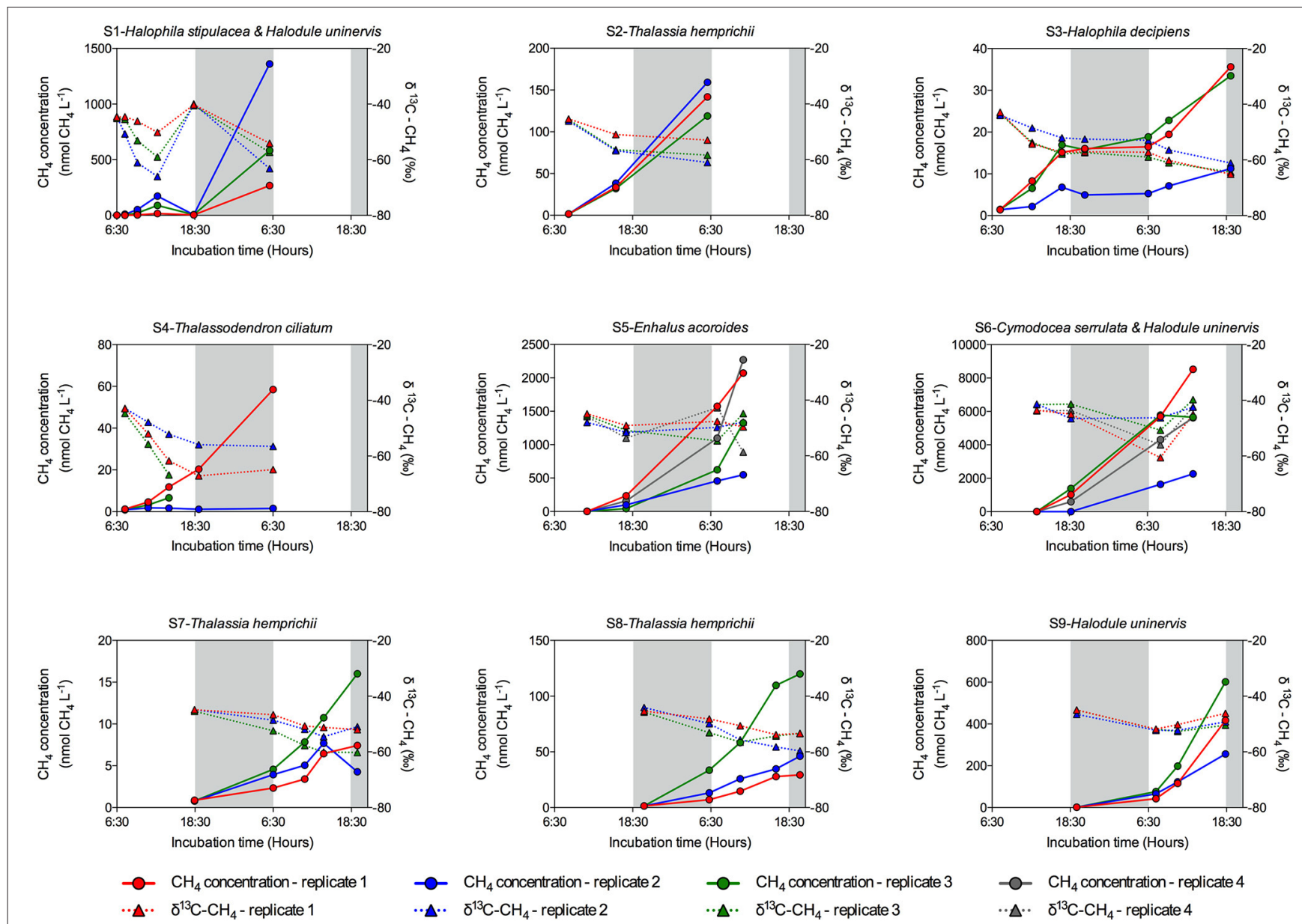

FIGURE 2 | Evolution of $\mathrm{CH}_{4}$ concentration (circles and solid lines) and its isotopic $\left(\delta^{13} \mathrm{C}_{-} \mathrm{CH}_{4}\right)$ signature (triangles and dashed lines) in the sediment and seagrass incubations for each seagrass station. Data from each replicate (in color code) are shown. Gray shaded area corresponds to night time. Note the different scale in $Y$ left axis.

production rates measured under light conditions $(3.30 \pm 0.92$ $\mu \mathrm{mol} \mathrm{CH} \mathrm{m}^{-2} \mathrm{~h}^{-1}$ ) did not differ from the annual mean of the rates measured under dark conditions $\left(4.22 \pm 0.92 \mu \mathrm{mol} \mathrm{CH}_{4}\right.$ $\left.\mathrm{m}^{-2} \mathrm{~h}^{-1}\right)$.

Finally, the two different technical approaches used to measure $\mathrm{CH}_{4}$ production rate on E. acoroides seagrass meadow (Station S5) gave similar results. The $\mathrm{CH}_{4}$ production rate for E. acoroides using the headspace technique resulted in $115.62 \pm$ $23.7 \mu \mathrm{mol} \mathrm{CH} \mathrm{Cm}^{-2} \mathrm{~d}^{-1}$ and the $\mathrm{CH}_{4}$ production rate using the technique of the closed recirculating circuits for the same date resulted in $114.5 \pm 59.4 \mu \mathrm{mol} \mathrm{CH}_{4} \mathrm{~m}^{-2} \mathrm{~d}^{-1}$.

\section{DISCUSSION}

Here, we present, for the first time, rates of $\mathrm{CH}_{4}$ production by seagrass ecosystems in the Red Sea. The mean $\mathrm{CH}_{4}$ production rate for the seagrass meadows analyzed in this study was $85.09 \pm 27.8 \mu \mathrm{mol} \mathrm{CH} \mathrm{CH}^{-2} \mathrm{~d}^{-1}$, ranging from $0.81 \pm 0.34$ to $401.32 \pm 95.59 \mu \mathrm{mol} \mathrm{CH} \mathrm{m}^{-2} \mathrm{~d}^{-1}$ on average for a Thalassia hemprichii meadow and a Cymodocea serrulata and
Halodule uninervis mixed meadow, respectively. These rates measured here are consistent with previous estimates in seagrass meadows elsewhere, with mean rates ranging from 5.8 to 307.2 $\mu \mathrm{mol} \mathrm{CH} \mathrm{m}^{-2} \mathrm{~d}^{-1}$ for Syringodium sp. and Zostera noltii, respectively (Table 1). From all the seagrass species analyzed here, Enhalus acoroides is the only one for which $\mathrm{CH}_{4}$ production rates were previously reported (Alongi et al., 2008), with very similar values. The $\mathrm{CH}_{4}$ production rate reported for this seagrass in Indonesia was on average $118.8 \mu \mathrm{mol} \mathrm{CH}_{4} \mathrm{~m}^{-2}$ $\mathrm{d}^{-1}$ (ranging from 4.5 to $233.1 \mu \mathrm{mol} \mathrm{CH}_{4} \mathrm{~m}^{-2} \mathrm{~d}^{-1}$ ) and the rate reported here for the Red Sea was $115.6 \pm 23.7 \mu \mathrm{mol}$ $\mathrm{CH}_{4} \mathrm{~m}^{-2} \mathrm{~d}^{-1}$ (Table 2) for the single sampling on April and $96.2 \pm 17.9 \mu \mathrm{mol} \mathrm{CH}_{4} \mathrm{~m}^{-2} \mathrm{~d}^{-1}$ when averaging the rates measured along a year (Figure 5). The high variability that we observe in our measurements has been described as well for other systems, such as freshwater wetlands (EPA, 2010).

Methane production in Red Sea seagrass meadows increased with increasing organic matter content in the sediment (Figure 4A), in agreement with previous findings of higher $\mathrm{CH}_{4}$ 


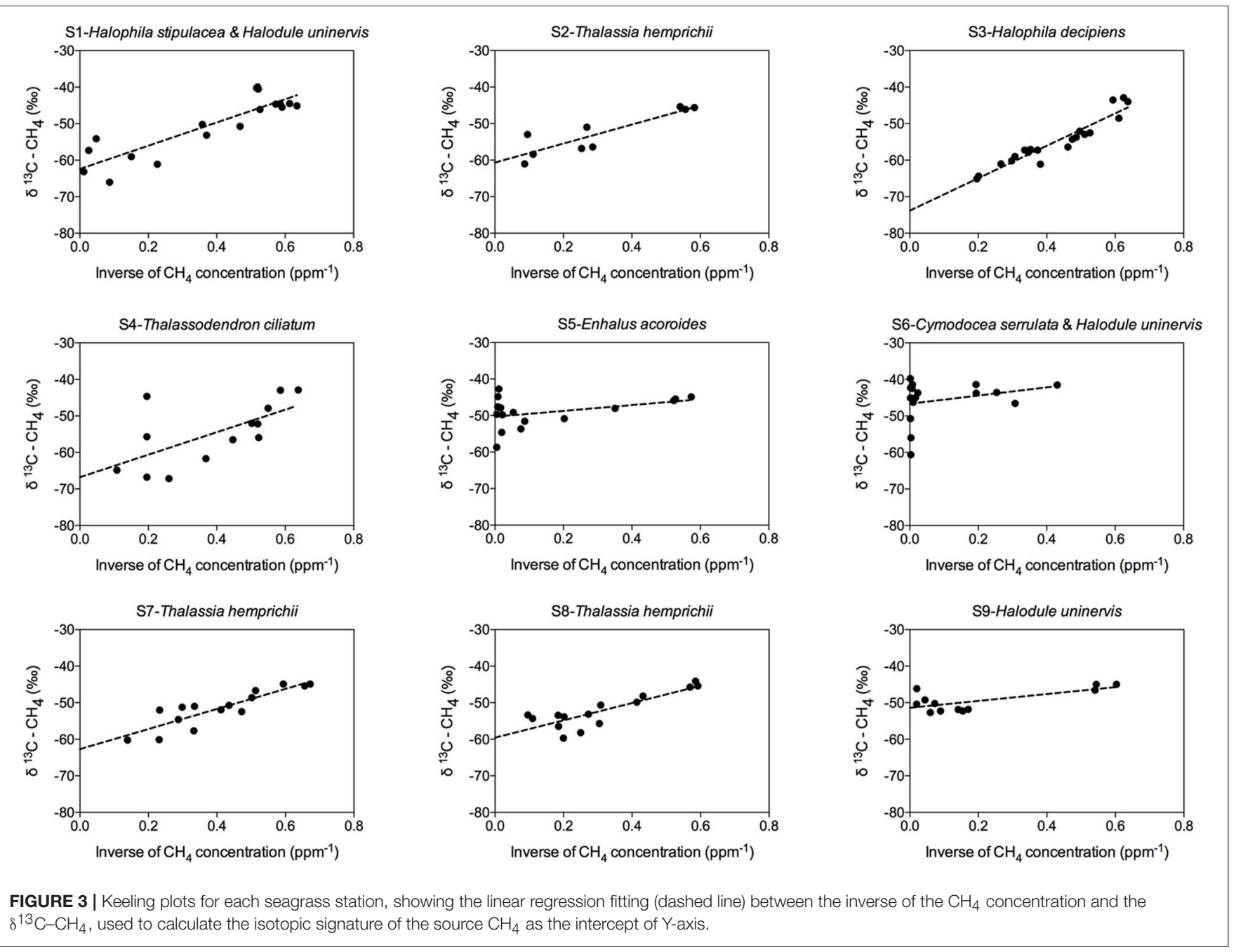

concentration in porewater of seagrass sediments compared to adjacent bare sediments (Barber and Carlson, 1993). Similarly, $\mathrm{CH}_{4}$ fluxes were more than 4-fold higher in Zostera noltii sediments compared to bare sediments in a temperate intertidal system (12.8 and $3 \mu \mathrm{mol} \mathrm{CH} \mathrm{m}^{-2} \mathrm{~h}^{-1}$, respectively) (Bahlmann et al., 2015), and Alongi et al. (2008) reported an increase in $\mathrm{CH}_{4}$ release associated to an increase in seagrass productivity. Altogether, our findings and consistent literature reports suggest that organic exudates from seagrasses are fueling a complex microbial community including methanogenic Archea. Moreover, a trend toward increasing $\mathrm{CH}_{4}$ production with increasing salinity (Figure 4B) suggests that salinity slightly enhances $\mathrm{CH}_{4}$ production in the Red Sea, contrary to what has been previously described for estuaries and intertidal systems with freshwater inputs (Bartlett et al., 1987; Middelburg et al., 2002; Deborde et al., 2010). However, this relationship may be spurious, rather than causal, as salinity, increasing from south to north along the Red Sea, is also related to gradients in climate and productivity (Raitsos et al., 2013; Wafar et al., 2016), which may be driving the apparent relationship with salinity. Moreover, the highest salinity was observed in enclosed coastal lagoons, suggesting high rates of $\mathrm{CH}_{4}$ production to be reached in these environments. Similarly, $\mathrm{CH}_{4}$ production increased with seawater temperature, accounting for $25 \%$ of the variability in seagrass meadows along the Red Sea (Figure 4C). Barber and Carlson (1993) also reported the lowest values of $\mathrm{CH}_{4}$ concentration in porewater of Thalassia testudinum sediments in Florida at $22{ }^{\circ} \mathrm{C}$ during winter. However, we did not detect any clear seasonal pattern in the $\mathrm{CH}_{4}$ production for the E. acoroides meadow (Figure 5), even though the seawater temperature ranged from $22{ }^{\circ} \mathrm{C}$ in February to $34^{\circ} \mathrm{C}$ in August, during our study. This again suggest that, as for the positive relationship between salinity and $\mathrm{CH}_{4}$ production, temperature may reflect north-south gradients in the Red Sea rather than a functional response. Similarly, we did not detect any clear diurnal patter in $\mathrm{CH}_{4}$ production rates (Figures 2, 6). For some of our incubations, the $\mathrm{CH}_{4}$ concentration remains stable during night time (Figure $2 \mathrm{~S} 3$, S7, and S9) but for others, the $\mathrm{CH}_{4}$ concentration seems to increase faster during night time (Figure $2 \mathrm{~S} 1$ ). Our findings are in contrast with previous studies where $\mathrm{CH}_{4}$ concentration in Thalassia testudinum rhizosphere followed diurnal cycles, 


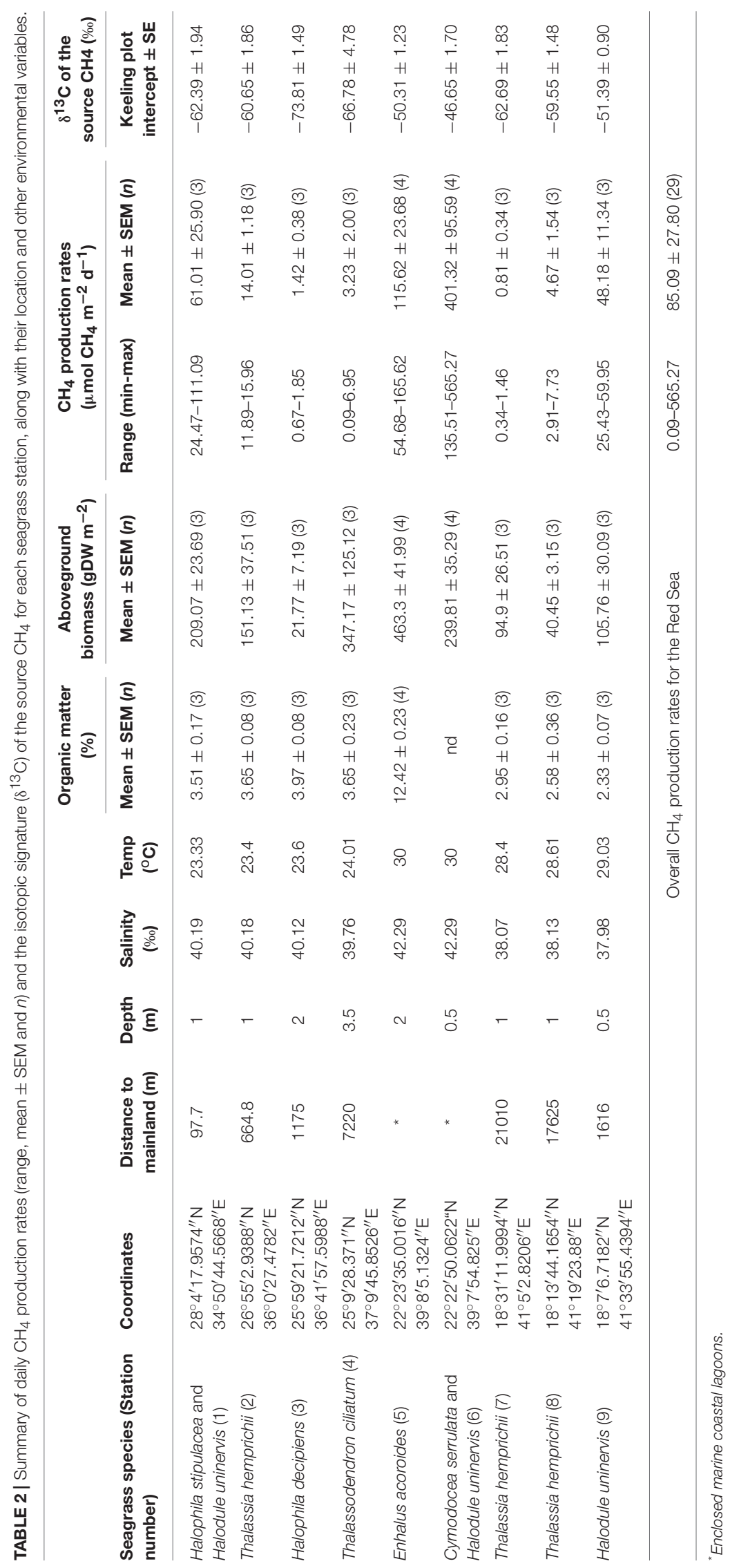



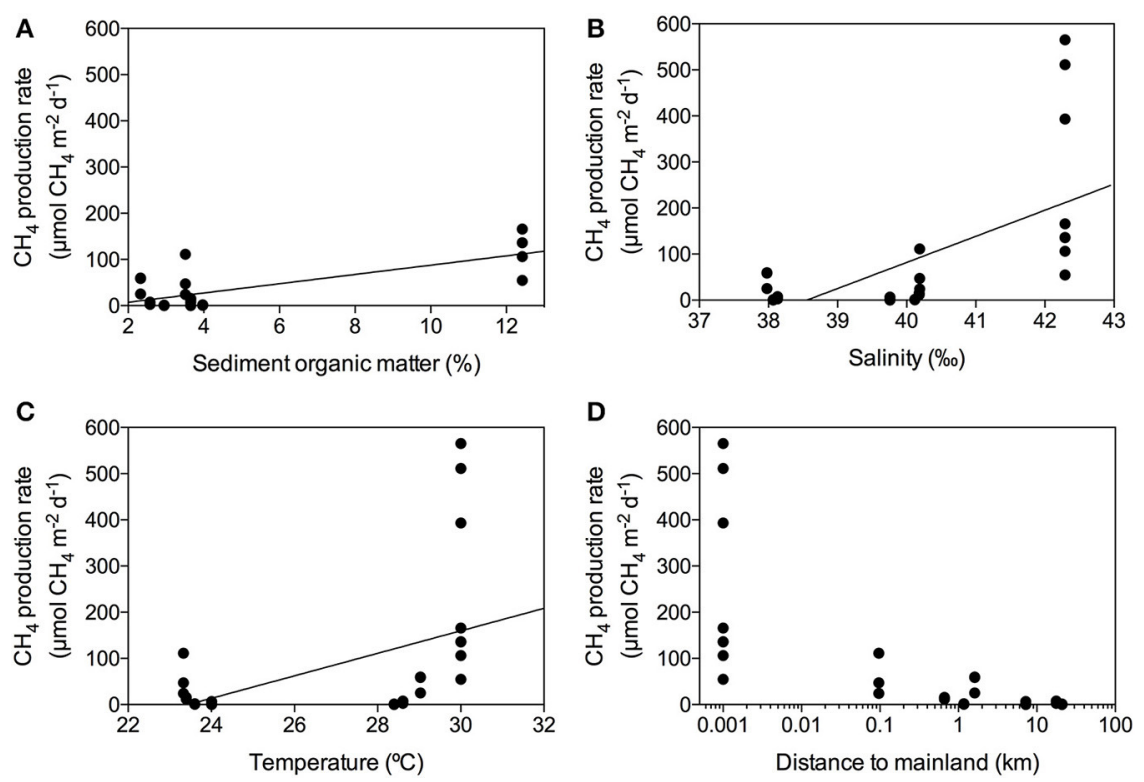

FIGURE 4 | Linear response of $\mathrm{CH}_{4}$ production rates to changes in sediment organic matter content (A), salinity (B) and temperature (C), showing the fitted linear model (solid line). Decline of $\mathrm{CH}_{4}$ production rates with increasing distance from the seagrass meadow to mainland (D).
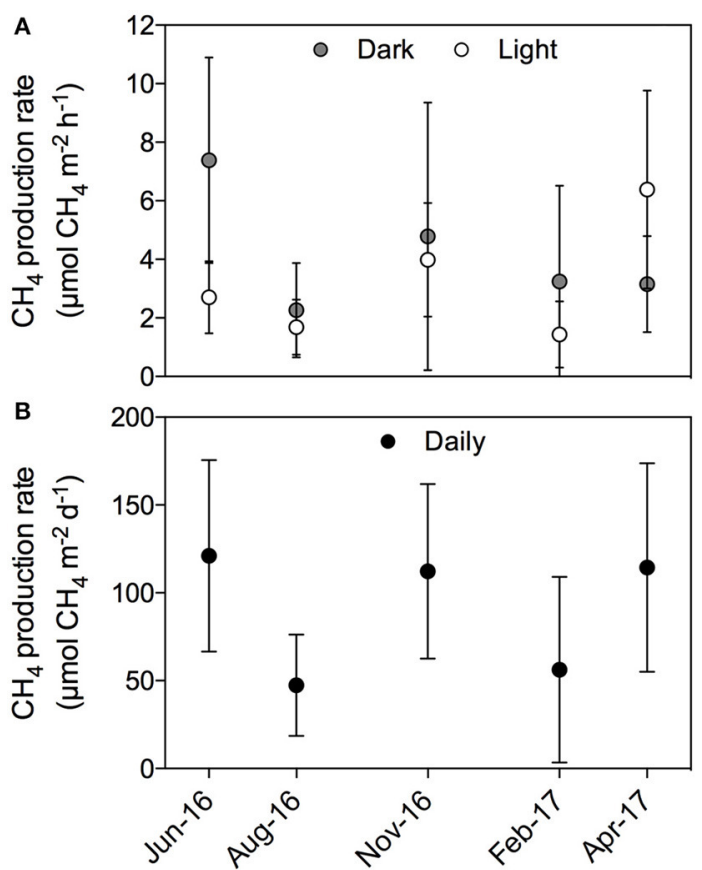

Sampling time

FIGURE 5 | $\mathrm{CH}_{4}$ production rates measured periodically during 1 year on Enhalus acoroides seagrass meadow (Station S5). (A) $\mathrm{CH}_{4}$ production rates measured during light (open circles) and dark (gray circles) conditions. (B) Daily $\mathrm{CH}_{4}$ production rates.

with minimum values coinciding with maximum oxygen levels (Oremland and Taylor, 1977) and higher $\mathrm{CH}_{4}$ fluxes during night in an intertidal Zostera noltii meadow (Bahlmann et al.,

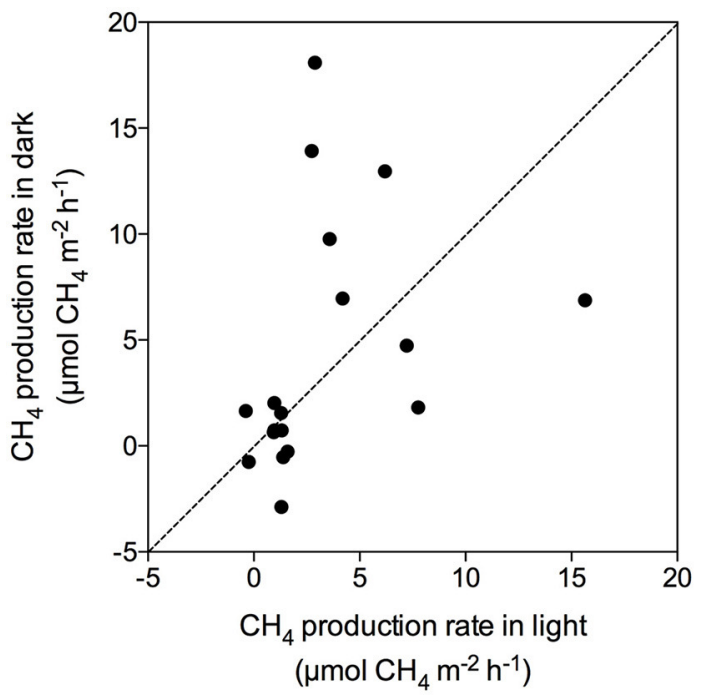

FIGURE 6 | Relationship of $\mathrm{CH}_{4}$ production rates measured under light and dark conditions, showing line 1:1 (dashed line).

2015), suggesting $\mathrm{CH}_{4}$ oxidation by photosynthetic oxygen. Part of the $\mathrm{CH}_{4}$ produced in seagrass meadows can be oxidized before reaching the atmosphere by methanotrophic bacteria inhabiting seagrass sediments (Jones et al., 2003) consisting of an anaerobic consortium between Archea and sulfate-reducing bacteria (Boetius et al., 2000). Similarly, Oremland and Taylor (1977) found that $\mathrm{CH}_{4}$ concentration within aerenchymatic seagrass tissues was much lower than the concentration recorded in the rhizosphere, suggesting the presence of methanotrophic 
bacteria inhabiting the rhizome surface. The fluctuations in $\mathrm{CH}_{4}$ concentration and in its isotopic composition during our incubations (Figure 2), points out that both methanogenesis and methanotrophy are happening concurrently in Red Sea seagrass meadows. Bacterial methanogenesis depletes total $\mathrm{CH}_{4}$ in ${ }^{13} \mathrm{C}$, shifting to lighter isotopic signature with respect to the starting $\mathrm{CH}_{4}$ isotopic values, whereas $\mathrm{CH}_{4}$ oxidation by bacteria enriches total $\mathrm{CH}_{4}$ in ${ }^{13} \mathrm{C}$, shifting to heavier isotopic signature (Whiticar, 1990). The mean $\delta^{13} \mathrm{C}$ of the $\mathrm{CH}_{4}$ produced by seagrasses in the Red Sea $(-59.36 \%)$ confirmed its biogenic origin. The isotopic signature of biogenic $\mathrm{CH}_{4}$ ranges from -40 to $-80 \%$, depending on the isotopic signature of the methanogenic substrates (Reeburgh, 2014).

Interestingly, we detected a sharp decrease in seagrass $\mathrm{CH}_{4}$ production rates with increasing distance to the mainland, with the lowest rates detected in pristine and remote seagrass meadows (Figure 4D). Eutrophication has been related to an increase in $\mathrm{N}_{2} \mathrm{O}$ and $\mathrm{CH}_{4}$ production in shallow coastal areas (Bange, 2006), suggesting that further deterioration and anthropogenic disturbance on seagrass ecosystems may lead to an increase in $\mathrm{CH}_{4}$ production and therefore $\mathrm{CH}_{4}$ emissions. However, the Saudi Red Sea coast is relatively pristine, except for high discharges associated with main urban areas, so the reasons for the decrease in seagrass $\mathrm{CH}_{4}$ production rates with increasing distance to the mainland remain unclear. $\mathrm{CH}_{4}$ production rates were independent of the aboveground seagrass biomass and the $\mathrm{C}$ and $\mathrm{N}$ sediment content. The aboveground seagrass biomass varies greatly among species, depending on their size, tissue turnover and growth rate (Duarte and Chiscano, 1999). Thus, the difference in $\mathrm{CH}_{4}$ production rates might be due to different sediment microbial communities, specific of each seagrass species.

Net fluxes or emissions to the atmosphere of the $\mathrm{CH}_{4}$ produced by these ecosystems will depend on the solubility of $\mathrm{CH}_{4}$ in seawater as a function of salinity and temperature, the saturation ratio (observed/equilibrium concentrations), the airwater concentration gradient and the exchange coefficient as a function of wind or turbulence (Middelburg et al., 2002). Here, we report $\mathrm{CH}_{4}$ production rates by seagrasses, but due to the high salinity and temperatures found in the Red Sea waters that reduce the solubility of $\mathrm{CH}_{4}$ leading to low equilibrium levels and high saturation ratios, combined with low atmospheric concentrations, we believe that the air-water concentration gradient and the prevalent winds are enough to force a significant flux of $\mathrm{CH}_{4}$ from seawater to the atmosphere.

\section{REFERENCES}

Alongi, D. M., Trott, L. A., Undu, M. C., and Tirendi, F. (2008). Benthic microbial metabolism in seagrass meadows along a carbonate gradient in Sulawesi, Indonesia. Aquat. Microb. Ecol. 51, 141-152. doi: 10.3354/ ame01191

Bahlmann, E., Weinberg, I., Lavrič, J., Eckhardt, T., Michaelis, W., Santos, R., et al. (2015). Tidal controls on trace gas dynamics in a seagrass meadow of the Ria Formosa lagoon (southern Portugal). Biogeosciences 12, 1683-1696. doi: 10.5194/bg-12-1683-2015
Assuming that the net $\mathrm{CH}_{4}$ produced by seagrass ecosystems is emitted to the atmosphere, the $\mathrm{CH}_{4}$ emissions of Red Sea seagrass meadows would be 19.3-70.9-fold higher, on average, than the emissions reported for the open ocean, with emissions ranging from 1.2 to $4.4 \mu \mathrm{mol} \mathrm{m}{ }^{-2} \mathrm{~d}^{-1}$ (Holmes et al., 2000; Oudot et al., 2002; EPA, 2010). Moreover, taking in account the range of global estimates for seagrass coverage, from 0.15 $\times 10^{6}$ to $4.32 \times 10^{6} \mathrm{Km}^{2}$ (Duarte, 2017) and using the mean seagrass $\mathrm{CH}_{4}$ production rate calculated by compounding our estimates with those available in the literature $(105.8 \pm 34.4$ $\mu \mathrm{mol} \mathrm{CH}_{4} \mathrm{~m}^{-2} \mathrm{~d}^{-1}$ ), the global $\mathrm{CH}_{4}$ production and emission by seagrass ecosystems could range from 0.09 to $2.7 \mathrm{Tg} \mathrm{yr}^{-1}$. Because $\mathrm{CH}_{4}$ emission by seagrass ecosystems had not been included in previous global estimates, the estimate provided here would increase the contribution of marine global emissions, hitherto estimated at $9.1 \mathrm{Tg} \mathrm{yr}^{-1}$ (EPA, 2010), by about $30 \%$. In terms of $\mathrm{CO}_{2}$-equivalents, calculated with the global warming potential for a time horizon of 100 years taking in account the climate-carbon feedback (IPCC, 2013), the $\mathrm{CH}_{4}$ emissions by seagrass ecosystems would represent $3.2-90.9 \mathrm{Tg} \mathrm{CO}_{2-\text { eq }}$ $\mathrm{yr}^{-1}$. This would imply a modest, $4.8 \%$, reduction in the carbon sink capacity of seagrass ecosystems, estimated between 65.5 and $1,887.5 \mathrm{Tg} \mathrm{CO}_{2} \mathrm{yr}^{-1}$ for the lower and upper limit of the seagrass coverage range (Duarte et al., 2010). However, these estimates are tentative for both the regional variation in $\mathrm{CH}_{4}$ emissions by seagrass ecosystems and the poorly constrained global seagrass area. In any case, the first order estimate of potential contribution of seagrass ecosystems to marine $\mathrm{CH}_{4}$ emissions provides sufficient evidence of the relevance of these fluxes as to include seagrass ecosystems in future assessments of the global $\mathrm{CH}_{4}$ budgets.

\section{AUTHOR CONTRIBUTIONS}

NG-B and CD designed the study and collected samples. NG-B acquired and analyzed the data. NG-B and CD interpreted data, wrote and reviewed the manuscript.

\section{ACKNOWLEDGMENTS}

This research was supported by King Abdullah University of Science and Technology (KAUST) through the baseline fund to CD. We thank Paloma Carrillo de Albornoz for her assistance during field and laboratory work. We also thank the crew of R/V Thuwal for their assistance in our field work during the scientific cruise.

Bange, H. W. (2006). Nitrous oxide and methane in European coastal waters. Estuarine Coastal Shelf Sci. 70, 361-374. doi: 10.1016/j.ecss.2006.05.042

Barber, T. R., and Carlson, P. R. (1993). "Effects of seagrass die-off on benthic fluxes and porewater concentrations of $\sum \mathrm{CO}_{2}, \sum \mathrm{H}_{2} \mathrm{~S}$, and $\mathrm{CH}_{4}$ in florida bay sediments," in Biogeochemistry of Global Change, ed R. S. Oremland (Boston, MA: Springer), 530-550. doi: 10.1007/978-1-4615-28 $12-8 \_29$

Bartlett, K. B., Bartlett, D. S., Harriss, R. C., and Sebacher, D. I. (1987). Methane emissions along a salt marsh salinity gradient. Biogeochemistry 4, 183-202. doi: 10.1007/BF02187365 
Boetius, A., Ravenschlag, K., Schubert, C. J., and Rickert, D. (2000). A marine microbial consortium apparently mediating anaerobic oxidation of methane. Nature 407:623. doi: 10.1038/35036572

Bousquet, P., Ciais, P., Miller, J. B., Dlugokencky, E. J., Hauglustaine, D. A., Prigent, C., et al. (2006). Contribution of anthropogenic and natural sources to atmospheric methane variability. Nature 443, 439-443. doi: $10.1038 /$ nature 05132

Bruckner, A., Rowlands, G., Riegl, B., Purkis, S. J., Williams, A., and Renaud, P. (2012). Khaled bin Sultan Living Oceans Foundation Atlas of Saudi Arabian Red Sea Marine Habitats. Phoenix, AZ: Panoramic Press.

Conrad, R. (2007). Microbial ecology of methanogens and methanotrophs. Adv. Agron. 96, 1-63. doi: 10.1016/S0065-2113(07)96005-8

Deborde, J., Anschutz, P., Guérin, F., Poirier, D., Marty, D., Boucher, G., et al. (2010). Methane sources, sinks and fluxes in a temperate tidal Lagoon: the Arcachon lagoon (SW France). Estuarine Coastal Shelf Sci. 89, 256-266. doi: 10.1016/j.ecss.2010.07.013

Dlugokencky, E. J., Houweling, S., Bruhwiler, L., Masarie, K. A., Lang, P. M., Miller, J. B., et al. (2003). Atmospheric methane levels off: temporary pause or a new steady-state? Geophys. Res. Lett. 30:1992. doi: 10.1029/2003GL018126

Duarte, C. M. (2017). Reviews and syntheses: hidden forests, the role of vegetated coastal habitats in the ocean carbon budget. Biogeosciences 14:301. doi: 10.5194/bg-14-301-2017

Duarte, C. M., and Chiscano, C. L. (1999). Seagrass biomass and production: a reassessment. Aquat. Bot. 65, 159-174. doi: 10.1016/S0304-3770(99)00038-8

Duarte, C. M., Marbà, N., Gacia, E., Fourqurean, J. W., Beggins, J., Barrón, C., et al. (2010). Seagrass community metabolism: assessing the carbon sink capacity of seagrass meadows. Global Biogeochem. Cycles 24:GB4032. doi: 10.1029/2010GB003793

EPA (2010). Methane and Nitrous Oxide Emissions from Natural Sources, eds B. Anderson, K. Bartlett, S. Frolking, K. Hayhoe, J. Jenkins and W. Salas. Washington, DC: Environmental Protection Agency.

Gray, J. S. (1981). The Ecology of Marine Sediments. New York, NY: Cambridge University Press.

Holmes, M. E., Sansone, F. J., Rust, T. M., and Popp, B. N. (2000). Methane production, consumption, and air-sea exchange in the open ocean: an evaluation based on carbon isotopic ratios. Global Biogeochem. Cycles 14, 1-10. doi: 10.1029/1999GB001209

IPCC (2013). Climate change 2013: The Physical Science Basis. Contribution of Working Group I to the Fifth Assessment Report (AR5) of the Intergovernmental Panel on Climate Change. New York, NY: Cambridge University Press.

Jones, W. B., Cifuentes, L. A., and Kaldy, J. E. (2003). Stable carbon isotope evidence for coupling between sedimentary bacteria and seagrasses in a subtropical lagoon. Mar. Ecol. Progr. Ser. 255, 15-25. doi: 10.3354/meps255015

Karl, D. M., Beversdorf, L., Björkman, K. M., Church, M. J., Martinez, A., and Delong, E. F. (2008). Aerobic production of methane in the sea. Nat. Geosci. 1, 473-478. doi: 10.1038/ngeo234

Karl, D. M., and Tilbrook, B. D. (1994). Production and transport of methane in oceanic particulate organic matter. Nature 368, 732-734. doi: 10.1038/368732a0

Kirschke, S., Bousquet, P., Ciais, P., Saunois, M., Canadell, J. G., Dlugokencky, E. J., et al. (2013). Three decades of global methane sources and sinks. Nat. Geosci. 6, 813-823. doi: $10.1038 /$ ngeo 1955

Lashof, D. A., and Ahuja, D. R. (1990). Relative contributions of greenhouse gas emissions to global warming. Nature 344, 529-531. doi: 10.1038/344529a0

McNorton, J., Chipperfield, M. P., Gloor, M., Wilson, C., Feng, W., Hayman, G. D., et al. (2016). Role of $\mathrm{OH}$ variability in the stalling of the global atmospheric CH 4 growth rate from 1999 to 2006. Atmos. Chem. Phys. 16, 7943-7956. doi: 10.5194/acp-16-7943-2016

Melton, J., Wania, R., Hodson, E., Poulter, B., Ringeval, B., Spahni, R., et al. (2013). Present state of global wetland extent and wetland methane modelling: conclusions from a model intercomparison project (WETCHIMP). Biogeosciences 10, 753-788. doi: 10.5194/bg-10-753-2013
Middelburg, J. J., Nieuwenhuize, J., Iversen, N., Høgh, N., De Wilde, H., Helder, W., et al. (2002). Methane distribution in European tidal estuaries. Biogeochemistry 59, 95-119. doi: 10.1023/A:10155151 30419

Oremland, R. S. (1975). Methane production in shallow-water, tropical marine sediments. Appl. Microbiol. 30, 602-608.

Oremland, R. S., and Taylor, B. F. (1977). Diurnal fluctuations of O2, N2, and CH4 in the rhizosphere of Thalassia testudinum. Limnol. Oceanogr. 22, 566-570. doi: 10.4319/lo.1977.22.3.0566

Oudot, C., Jean-Baptiste, P., Fourré, E., Mormiche, C., Guevel, M., Ternon, J.-F., et al. (2002). Transatlantic equatorial distribution of nitrous oxide and methane. Deep Sea Res. Part I Oceanogr. Res. Pap. 49, 1175-1193. doi: 10.1016/S0967-0637(02)00019-5

Raitsos, D. E., Pradhan, Y., Brewin, R. J. W., Stenchikov, G., and Hoteit, I. (2013). Remote sensing the phytoplankton seasonal succession of the Red Sea. PLoS ONE 8:e64909. doi: 10.1371/journal.pone.0064909

Rasul, N. M. A., Stewart, I. C. F., and Nawab, Z. A. (2015). "Introduction to the Red Sea: its origin, structure, and environment," in The Red Sea: The Formation, Morphology, Oceanography and Environment of a Young Ocean Basin, eds N. M. A. Rasul and I. C. F. Stewart (Berlin; Heidelberg: Springer Berlin Heidelberg), $1-28$.

Reeburgh, W. S. (2014). "Global methane biogeochemistry," in Treatise on Geochemistry, 2nd Edn, eds H. D. Holland and K. K. Turekian (Oxford: Elsevier), 71-94.

Rhee, T. S., Kettle, A. J., and Andreae, M. O. (2009). Methane and nitrous oxide emissions from the ocean: a reassessment using basin-wide observations in the Atlantic. J. Geophys. Res. 114:D12304. doi: 10.1029/2008JD011662

Rigby, M., Prinn, R. G., Fraser, P. J., Simmonds, P. G., Langenfelds, R. L., Huang, J., et al. (2008). Renewed growth of atmospheric methane. Geophys. Res. Lett. 35:L22805. doi: 10.1029/2008GL036037

Thom, M., Bösinger, R., Schmidt, M., and Levin, I. (1993). The regional budget of atmospheric methane of a highly populated area. Chemosphere 26, 143-160. doi: 10.1016/0045-6535(93)90418-5

Turner, A. J., Frankenberg, C., Wennberg, P. O., and Jacob, D. J. (2017). Ambiguity in the causes for decadal trends in atmospheric methane and hydroxyl. Proc. Nat. Acad. Sci. U.S.A. 114, 5367-5372. doi: 10.1073/pnas.1616020114

Wafar, M., Qurban, M. A., Ashraf, M., Manikandan, K., Flandez, A. V., and Balala, A. C. (2016). Patterns of distribution of inorganic nutrients in Red Sea and their implications to primary production. J. Mar. Syst. 156, 86-98. doi: 10.1016/j.jmarsys.2015.12.003

Whiticar, M. J. (1990). A geochemial perspective of natural gas and atmospheric methane. Org. Geochem. 16, 531-547. doi: 10.1016/0146-6380(90)90068-B

Wiesenburg, D. A., and Guinasso, N. L. (1979). Equilibrium solubilities of methane, carbon monoxide, and hydrogen in water and sea water. J. Chem. Eng. Data 24, 356-360. doi: 10.1021/je60083a006

Wilson, S. T., Böttjer, D., Church, M. J., and Karl, D. M. (2012). Comparative assessment of nitrogen fixation methodologies, conducted in the oligotrophic North Pacific Ocean. Appl. Env. Microbiol. 78, 6516-6523. doi: 10.1128/AEM.01146-12

Conflict of Interest Statement: The authors declare that the research was conducted in the absence of any commercial or financial relationships that could be construed as a potential conflict of interest.

The reviewer MKD and handling Editor declared their shared affiliation.

Copyright (c) 2017 Garcias-Bonet and Duarte. This is an open-access article distributed under the terms of the Creative Commons Attribution License (CC BY). The use, distribution or reproduction in other forums is permitted, provided the original author(s) or licensor are credited and that the original publication in this journal is cited, in accordance with accepted academic practice. No use, distribution or reproduction is permitted which does not comply with these terms. 